of diabetes, galactosæmia, glycogen deposition disease, and many other abnormalities concerned with the metabolism of adrenal storoids, purines, metals, lipids, hæmoglobin and the clotting of blood, porphyrins, bile pigments and renal tubular transport. In most cases the abnormalities are the result of enzyme irregularities dependent on recessive genes. As Goldberg remarks, it would seem that no metabolic pathway is exempt from the occasional, and sometimes not so occasional, genetically expressed deviation.

In their paper on congenital abnormalities of the limbs, J. I. P. James and D. W. Lamb show that these may take many forms: the absence of a hand, arm or fibula, for example, extra digits, syndactyly, 'club foot', otc., along with an extensive list of less-serious defects. Some of them appear to bo the result of chromosome derangements, others are known to be produced by agents of external origin; while congenital dislocation of the hip is now thought to be brought about by maternal hormones, especially relaxin. Clubbed feet and related defects can be improved by gentle manipulation and strapping at an early age; a number of other abnormalities call for surgical treatment; but great care should be taken not to remove stumps of limbs which can be made use of in prosthetic replacement, with which, if in a simple form, the child should be allowed, to grow familiar as soon as possible.

A. D. M. Jackson deals with congenital abnormalities brought about by agents of external origin, of which the most general are infections. Leaving aside infections gaining entry at the act of birth, like gonococcal ophthalmia, and those passed on from mother to foetus at a late stage in pregnancy, like chickenpox and Coxsackie $B$ virus disease, Jackson draws on the investigation initiated by the Ministry of Health and General Register Office, in 1950, and a still larger one in Sweden. These investigations show that the most serious abnormalities are due to infections of rubella during the first three months of pregnancy. The effects are seen in highor rates than normal for abortions and stillbirths, low birth weight, cataract, heart defects, and deafness. The risk that a child will be born with some affliction is about 30 per cent, with deafness as the commonest; deafness appears to be the only serious handicap if the mother becomes infected at later stages in pregnancy. To avoid these defects the mother should be immunized against rubella before marriage; even passive immunization within a few days of exposure may be of some help.
The British investigation also covered the risk of abnormalities produced by other infections, such as measles, poliomyelitis and influenza, but no clear association between infection and abnormality could be established.

Among the congenital defects produced by external agents of an artificial kind, the tragedy of the thalidomide episode has directed attention to those resulting from drug treatment. J. M. Robson deals with these. Thalidomide itself is a mild sedative; even in large doses it produces scarcely any toxic effect on man and animals. Why it should exert such a drastic influence on the fœtus is a question which still remains obscure. There are other drugs, like sodium salicylate and nicotine, in wide clinical use which have not yet been shown to be teratogenic in man although in high doses they have serious effects on the foetuses of experimental animals. A number of other drugs seem to act in much the same way. The action on man of 5-hydroxytryptamine still awaits elucidation; it is naturally present in the body, but in large doses it produces many malformations in animals, probably because of its interference with placental function. Robson recommends that in introducing new drugs for clinical use great caution should be exercised over those which are teratogenic in experimental animals, particularly if there is a wide discrepancy between the dose which has a harmful effect on the foetus and that which is toxic to the mother.

The remaining paper in the symposium, by J. W. Millen, is on the effects of radiation. He refers to the large amount of work which has been done on experimental animals: many congenital abnormalities have been produced, affecting every organ system, and depending on the time, intensity and nature of the radiations, together with the stage in pregnancy. Experiences with therapeutic irradiation have shown that similar defects can be produced in man. The effect appears to be directly on the foetus, not mediated by the mother. Surveys of the results of the atomic bombs exploded in Japan have reported many cases of microcephaly, which is the only defect that can be linked directly with the intensity of exposure; but other effects may have been masked by fotal deaths. So far there is no convincing evidence that mutations can be produced by irradiation in man; and the risk of harmful mutations being caused by the background radiation of present-day living would seem not to be serious.

\section{R. Weatherall}

\title{
WORLD DIRECTORY OF VETERINARY SCHOOLS
}

\begin{abstract}
A World Directory of Veterinary Schools* has recently been published by the World Health Organization, Geneva, under the auspices of the Food and Agriculture Organization of the United Nations and the World Health Organization. There has, in the past, been no available source of information about veterinary schools as a whole, and the Directory will be of great use to all those concerned with veterinary science.

During the past decade and a half there have been great changes and extensions in veterinary schools. The end of the Second World War led to considerable changes in certain European countries; in some instances the changes were merely the result of opportunity after hostilities had ended and there was return to normal life, a matter merely of delay. Altered frontiers and other political matters resulted in changes. The achievement of self-government in certain former British territories and in those of other European powers has been an important

* World Directory of Veterinary Schools, 1963. (Published under the auspices of the Food and Agriculture Organization of the United Nation and the World Health Organization.) Pp. 216. $16 \mathrm{Sw}$. francs; $268.8 d$. $5 . .25$ dollars.
\end{abstract}

cause of development. Whereas there were 6 schools prior to 1947 in India there are now 16. Pakistan has 2.

The details for each country are set out according to a standard plan under the same sets of headings, beginning with tables showing the population of the country, the numbers of livestock and details of veterinary activity. In the case of each country a table is given of the veterinary schools, date of foundation, numbers of teaching staff, total enrolment and tuition fees. Information is given for each country concerning administration, conditions of admission, curriculum and examinations.

Scrutiny of the Directory shows extraordinary disparity in the numbers of graduates, the numbers of veterinary schools and the numbers of livestock in a country. It is of interest to compare essential figures given for livestock populations and the numbers of veterinarians. The figures for the United Kingdom concern only the numbers resident in the country, and about 1,800 of the graduates are resident overseas. A defect in the quotations of essen. tial figures given in the first table for each country is that there has been some or even considerable delay in 
reporting them; those given for the United Kingdom refer to 1959. Unfortunately, the wording used in these tables is not very lucid.

The following table is made up from data in the book. It has been prepared by placing the order of the countries according to the numbers of the larger farm animals: horses, cattle, camels and domestic water buffaloes; for the purposes of demonstration of animal wealth the smaller farm animals can be ignored. This table shows the enormous farm animal wealth of India, with more than double the numbers of any other country. It also brings out the very small numbers in many countries of great prominence.

$\begin{array}{cccl}\begin{array}{c}\text { Farm livestock } \\ \text { (large animals) } \\ \text { (millions) }\end{array} & \begin{array}{c}\text { Veterinary } \\ \text { schools }\end{array} & \begin{array}{c}\text { No. of } \\ \text { veterinarians }\end{array} \\ 207 & 16 & 5,583 & \text { India } \\ 96 & 18 & 20,861 & \text { United States } \\ 85 & 8 & 2,325 & \text { Brazil } \\ 83 & 23 & \times \times & \text { U.S.S.R. } \\ 44 & 3 & 2,000 & \text { Argentine } \\ 32 & 3 & 508 & \text { Mexico } \\ 32 & 2 & 490 & \text { Pakistan } \\ 20 & 3 & 4,379 & \text { France } \\ 18 & 1 & 185 & \text { Kenya } \\ 17 & 1 & 1,262 & \text { Turkey }\end{array}$

\section{NATURAL GAS IN THE NETHERLANDS}

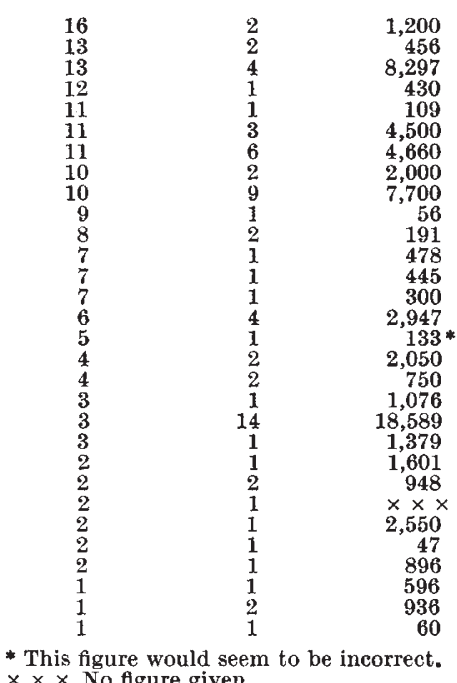

$x \times \times$ No figure given.
Australia Colombia

German Federal Republic Union of South Africa Thailand Poland United Kingdom Canada Italy Sudan Indonesia Iran Uruguay Venezuela Yugoslavia Romania Czechoslovakia Ireland Denmark Japan Netherlands Austria Greece Hungary Iraq Sweden Norway Switzerland Viet Nam

W. A. PooL
$\mathrm{T}$ HE first natural gas field in Holland was discovered and developed by the N.V. Nederlandse Aardolie Maatschappij (N.A.M.) in 1948 in the province of Drenthe, at Coevorden. The gas-bearing formation is at a depth of more than $9,000 \mathrm{ft}$. Coevorden proved to be a small but exploitable field. Later, other small gas fields were discovered in the north-eastern provinces of Drenthe and Overijssel, also in the western province of South Holland, but the amount of gas available was relatively small, some 520,000 cubic yards per day, and at that rate a calculated twenty years' supply. In terms of energy this quantity of gas per day is equivalent to about 150,000 tons of coal per year; in 1954 the coal production of the Netherlands amounted to 12 million tons; thus the quantity of natural gas available in that year did not represent more than 1 per cent of the total coal production.

It was not until August 1959 that the natural gas situation was dramatically changed by the drilling of a well at Slochteren in the province of Groningen which proved the existence of an enormous gas-field, actually the third largest in the world, Panhandle, Texas, being the largest, followed by the Hassi R'Mel gas-field in the Sahara as second. After Slochteren No. 1 (as it was called), there followed successful strikes of gas at Delfzijl and Slochteren (No. 2) in 1960, at Ten Boer in 1961, at Nordbroek in 1962 and at Schildmeer in February 1963, all in the province of Groningen.
The total proved natural gas reserves in the Groningen province alone are so far estimated at some 520,000 million cubic yards, the largest in Europe. Compared with the French gas-field at Lacq in France, with estimated reserves of 230,000 million cubic yards, the Groningen field is more than double the size. A further factor is that the geographical spread of this natural gas deposit may not as yet have been completely determined; possibilities of extensions under the North Sea by off-shore drilling, equally eastwards into West Germany, are by no means unlikely.

Production from the Gronginen region will be carried out by N.A.M., a joint venture of the Esso Petroleum and Shell Companies. N.A.M. and the State Mines Department of the Netherlands have formed a partnership "under which they will share the costs and the proceeds of the development of the natural gas on a basis of 60 and 40 per cent respectively". “. . . N.A.M. will deliver all the Groningen natural gas to a new company called N.V. Nederlandse Gasunie, which was formed on April 6 this year. Forty per cent of the new company is owned by the State Mines, 25 per cent each by Esso and Shell. and the remaining 10 per cent by the Dutch Government. Its function is to purchase, transport and market natural gas in the Netherlands". Further information on these extremely important developments is given in an illustrated article in a recent issue of Esso Magazine (12. No. $3 ; 1963)$.
H. B. Milner

\section{SEARCH FOR PETROLEUM IN AUSTRALIA}

$I^{N}$ N 1900 there was an accidental discovery of natural gas at Roma, some $\mathbf{3 0 0}$ miles west-north-west of Brisbane, Queensland. Since that time there have been many shortlived and unsuccessful attempts to locate oil and gas deposits in commercial quantities in that area. But prospecting for oil still continues with persistent enthusiasm and cautious confidence not only in this region but also in other potential places in Australia. As recently as 1959 the Commonwealth Government enacted the Petroleum Search Subsidy Act enabling exploration companies to carry out geophysical or bore-hole surveys for new sub- surface stratigraphical information or in prospecting for petroleum. The Act provides for subsidy for the cost of operations subject to approval of projects by the Minister of National Development. On behalf of the Minister, thr Bureau of Mineral Resources, Geology and Geophysics must examine and approve applications made under the Act, maintain surveillance of the operations and, in due course, publish the results. Thus has been provided a new stimulus in the time-long search for oil in this continent. and four publications recently issued by the Department of National Development (Bureau of Mineral Resources) 